\title{
Effect of manila palm (Adonidia merrillii Becc.) supplementation on production performance, rumen fermentation, hematology and eradication of gastro-Intestinal nematodes of goat
}

Thitima Norrapoke ( $D$ oreo99@windowslive.com )

Kalasin University Faculty of Agricultural Technology https://orcid.org/0000-0003-1980-882X

Tanitpan Pongjongmit

Kalasin University Faculty of Agricultural Technology https://orcid.org/0000-0002-7525-5951

\section{Research Article}

Keywords: Manila palm, rumen fermentation, nematodes

Posted Date: February 4th, 2022

DOI: https://doi.org/10.21203/rs.3.rs-1252280/v1

License: (c) (1) This work is licensed under a Creative Commons Attribution 4.0 International License.

Read Full License 
1 Effect of manila palm (Adonidia merrillii Becc.) supplementation on

2

3

4

5

6 Thitima Norrapoke and Tanitpan Pongjongmit *

7

8

9

10

11

12

13

14

15

16

17

18

19

20

21

22

23

24

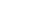

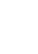

8

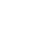
14

15

6

18

19

20

21

22

* Corresponding Author : Tanitpan Pongjongmit

production performance, rumen fermentation, hematology and eradication of gastro-Intestinal nematodes of goat

2 Department of Animal Production Technology, Faculty of Agricultural

Technology, Kalasin University, Kalasin Province, 46000, Thailand

24 E-mail address: tanitphan.po@ksu.ac.th; Tel.: +6682-9464993 


\section{Abstract}

The purpose of research was to understand the effect of manila palm (Adonidia merrillii Becc.) supplementation on production performance, rumen fermentation, hematology and eradication of gastro-intestinal nematodes of goat. Sixteen native crossbred goats the ages of 1-2 year are divided into 8 males and 8 females at initial body weight (BW) of $20 \pm 3.1 \mathrm{~kg}$ was used in this experiment. The experiment was a randomized complete block design (RCBD) trial was planned to compare 4 supplementation forms of ivermectin and manila palm. Group 1 received ivermectin 3.03 microgram $/ \mathrm{kg}$ body weight. Groups 2, 3 and 4 were treated with seeds in manila palm, manila palm peel and manila palm whole extract $5 \mathrm{ml} /$ goat weight 1 $\mathrm{kg}$, respectively. Results revealed that average daily gain, feed conversion ratio, feed intake, digestibility, BUN, Hct, ruminal $\mathrm{pH}, \mathrm{NH}_{3}-\mathrm{N}$, temperature, total VFA and butyric acid were non significantly $(\mathrm{P}>0.05)$. The concentration of acetic acid was decreased by supplementation of manila palm $(\mathrm{P}<0.05)$ whereas propionic acid was increased $(\mathrm{P}<0.05)$ by goat fed manila palm especially manila palm whole extract $5 \mathrm{ml}$ / goat weight $1 \mathrm{~kg}$ when compare with author group. However, $\mathrm{CH}_{4}$ was decreased $(\mathrm{P}<0.05)$ as result of supplementation of manila palm compared to author group. Whereas, goats fed manila palm whole extract decreased the protozoal population $(\mathrm{P}<0.05)$. After the goat receives treatment at $1,3,14$ days showed a decrease in the goat's fecal egg count was no significant $(\mathrm{P}>0.05)$. After receives treatment at 7 and 21 days showed a decrease in the goat's fecal egg count had significant $(\mathrm{P}<0.05)$. After that at 28 and 35 days the results showed increase in the goat's fecal egg count had significant $(\mathrm{P}<$ 0.05). This study concluded that supplementation of manila palm whole extract $5 \mathrm{ml} /$ goat weight $1 \mathrm{~kg}$ resulted in increased propionic acid and decreased $\mathrm{CH} 4$ production, protozoa population and fecal eggs counts. This study concluded that feeding of manila palm whole extract $5 \mathrm{ml} /$ goat weight $1 \mathrm{~kg}$ is recommended because it has the best level for use as animal feed supplementation.

Keywords: Manila palm, rumen fermentation, nematodes 


\section{Introduction}

Current, the goat farming profession is becoming very popular with Thai farmers. Market is a very interesting new market. And goats are also considered major economic animals in Thailand. In 2017, there were 46,478 goats compared to 17,209 in 2012, or an annual increase of 170.08\%. (Planning Division Department of Livestock Development 2018). But the farming profession is still slowly growing not enough for consumers. Why many farmers give up. Due to problems with diseases and helminthiasis. Especially parasites that cause a lot of problems for farmers. If a goat has a large amount of internal helminths, it causes acute diseases and dies. But if there is not much volume, it may not be deadly, but it will cause the productivity to decrease. The solution for farmers is the use of deworming drugs. It also increases the cost of using deworming drugs. This can cause goats to tolerate or cause residues, which goes against the principle of halal feed. It is determined that both meat and dairy feed must be safe and must come from safe feeding methods. Use clean feed ingredients, free from residues, and give them to goats. Eating only plants does not use meat mixtures such as brain, blood, bones. In addition, hormonal substances are prohibited. Accelerate growth (growth promoter) and antibiotics (Semae 2007). In line with the wisdom of thai villagers, many herbs are used as parasitic drugs. For example, the neem tree, cassod tree, papaya, lok hat, tamarind, betel nut, manila Palm (Limcharoen et al. 2013)

The use of herbs in ruminant feeds is mainly aimed at stimulates eating and digestion. Injury treatment and relief and get rid of parasites. Each herb contains an important active ingredient to increase the use of feed and the treatment of animal injuries. The active ingredient contained in herbs is a secondary substance present in plants, which has a wide use, covering the functioning of several systems of the body.

Manila palm (Adonidia merrillii Becc.) is a type of palm plant in the Arecaceae category. Manila palm contain arecoline in the seeds which has the properties of helping to excrete many types of parasites, whether it is tapeworm, helminthiasis nematode. It was found that the manila palm contained about $20.16 \mathrm{mg} / 100$ grams of tannins (Bassey et al. 2017). Therefore, the study of manila palm (Adonidia merrillii Becc.) supplementation on production performance, rumen fermentation, hematology and eradication of gastro-intestinal nematodes of goat. It's an interesting approach to take advantage of locally available herbs and reduce the use of antibiotics in goats. To increase the productivity of the animal's diet.

\section{Materials and methods}

\section{Animals, diets and experimental design}


Sixteen native crossbred goats the ages of 1-2 year are divided into 8 males and 8 females at initial body weight (BW) of $20 \pm 3.1 \mathrm{~kg}$ was used in this experiment. All animals were housed in individual pens and offered concentrate diet $(16 \% \mathrm{CP})$ at $2 \% \mathrm{BW}$. Rice straw, water and mineral salt block were offered ad libitum. The experiment was a randomized complete block design (RCBD) trial was planned to compare 4 supplementation forms of ivermectin and manila palm. Group 1 received ivermectin 3.03 microgram $/ \mathrm{kg}$ body weight. Groups 2, 3 and 4 were treated with seeds in manila palm, manila palm peel and manila palm whole extract $5 \mathrm{ml} /$ goat weight $1 \mathrm{~kg}$, respectively.

\section{Herbal Preparations}

Prepare the manila palm half soft, half mature and whole fruit (4-6 weeks) in fresh condition, and then baked at a temperature $60^{\circ} \mathrm{C}$. Then were ground through a $1 \mathrm{~mm}$ sieve size. Bring the amount $1 \mathrm{~kg}$ then add 1 liter of water after that boil and simmer about $200 \mathrm{ml}$ of extracted water, leave to cool and treat at $4{ }^{\circ} \mathrm{C}$.

\section{Data collection and samples analysis}

Animals were weighed at the beginning and at the end of each period for body weight change. Feed intakes were recorded throughout the experimental periods and were determined by subtracting the amount of feed refusal from that of feed offered to the animals after which feed refusal was discarded before morning feeding.

For feces was taken by rectal sampling method. Dry matter (DM) of feed and rice straw were determined by oven drying at $100{ }^{\circ} \mathrm{C}$ to a constant weight. The diet and feces were dried at $60{ }^{\circ} \mathrm{C}$ for $48 \mathrm{~h}$ then ground to pass through a $1 \mathrm{~mm}$ screen (Cyclotech Mill, Tecator, Hoganas, Sweden) and used for chemical analysis. The diets and feces were chemically analyzed for organic matter $(\mathrm{OM})$, ash, ether extract $(\mathrm{EE})$ and crude protein $(\mathrm{CP})$ according to AOAC (1990), neutral detergent fiber (NDF) and acid detergent fiber (ADF) according to Van Soest et al. (1991), acid insoluble ash (AIA) according to Schnieder and Flat (1975). Digestible organic matter fermented in the rumen (DOMR) and digestible organic matter intake (DOMI) were calculated following the method explained by (ARC 1984; Kearl 1982).

Ten milliliters of blood were sampled from the animals' jugular vein at 0,3 and $6 \mathrm{~h}$ after feeding on the $35^{\text {st }}$ day of period, plasma was harvested by centrifugation at $5,000 \times \mathrm{g}$ for $10 \mathrm{~min}$ and store at $-20^{\circ} \mathrm{C}$ until further analysis. Blood urea nitrogen (BUN) was determined according to the method of Crocker (1967), haematocrit (Hct) according to the method of Kaneko et al. (1997). Approximately $45 \mathrm{ml}$ of ruminal fluid samples were collected (also at 0 , 
3 and $6 \mathrm{~h}$ after feeding) on the $35^{\text {st }}$ day of period through a stomach tube connected to a vacuum pump. Ruminal fluid $\mathrm{pH}$ and temperature were immediately determined using a portable $\mathrm{pH}$ and temperature meter (HANNA Instruments HI 8424 microcomputer, Singapore). The rumen fluid was divided into 2 portions; in the first portion, $45 \mathrm{~mL}$ of rumen fluid was mixed with 5 $\mathrm{mL}$ of $1 \mathrm{~mol} \mathrm{H}_{2} \mathrm{SO}_{4}$, was centrifuged at $16,000 \times \mathrm{g}$ for $15 \mathrm{~min}$, and then was used for $\mathrm{NH}_{3}-\mathrm{N}$ analysis using the Kjeltech Auto 1030 Analyzer using Kjeldahl methods AOAC (1990), while total volatile fatty acid (VFA) and VFA profiles were performed using HPLC (instruments by controller water model 600E, Water model 484 UV detector, column Novapak C18, column size $4 \times 150 \mathrm{~mm}$, mobile phase $10 \mathrm{mM} \mathrm{H}_{2} \mathrm{PO}_{4}(\mathrm{pH} 2.5)$; ETL Testing Laboratory, Inc., Cortland, NY, USA) according to Samuel et al. (1997). In the last portion, $1 \mathrm{ml}$ of ruminal fluid was mixed with $9 \mathrm{ml}$ of formalin solution, and then its population of bacteria, protozoa and fungi were counted using a microscope with a hemocytometer (Boeco, Hamburg, Germany).

\section{Fecal sample Collection}

Fecal samples were collected at day 0 (pre-treatment) and days 1, 3, 7, 14, 21, 28 and 35 (post-treatment) stores directly from the anus. Put a plastic box tightly closed. Write the goat number and the date of collection. Store at $4{ }^{\circ} \mathrm{C}$ using the modified McMaster technique to determine the fecal egg count of Whitlock (1984).

\section{Statistical analysis}

Data were analyzed according to a randomized complete block design (RCBD) using Proc GLM/Proc Mix (SAS 1996). Treatment means were statistically compared by Duncan's New Multiple Range Test (Steel and Torrie 1997). Differences among means with $\mathrm{P}<0.05$ were accepted as representing statistically significant differences.

\section{Results and discussions}

The chemical composition of concentrates, rice straw, manila palm peel, seeds in manila palm and manila palm whole in the Table 1. Analysis of chemical compositions found that concentrates, rice straw, manila palm peel, seeds in manila palm and manila palm whole contained crud protein at $16.84,2.69,6.49,3.88$ and $4.31 \% \mathrm{DM}$ and NDF at 53.22, 82.20, 72.84, 57.26 and 68.63\%DM and ADF at 20.43, 43.90, 45.48, 22.90 and 38.98\%DM.

Influence of manila palm (Adonidia merrillii Becc.) supplementation with seeds in manila palm, manila palm peel and manila palm whole extract $5 \mathrm{ml} /$ goat weight $1 \mathrm{~kg}$, on production performance and feed intake compared ivermectin 3.03 microgram $/ \mathrm{kg}$ body weight ( Table 2.). The results showed that average daily gain, feed conversion ratio was non significantly $(\mathrm{P}>0.05)$. In line with Thongpea (2015) study the effect of tamarind seed 
supplementation at levels $2.5,5.0$ and $7.5 \mathrm{~g} / \mathrm{kg}$. BW/d. The results revealed that average daily gain, feed conversion ratio was non significantly $(\mathrm{P}>0.05)$. Total feed intake, intake of rice straw and concentrate in term of $\% \mathrm{BW}$ and $\mathrm{kg}, \mathrm{g} \mathrm{kg}^{-1} \mathrm{BW}^{0.75}$ was non significantly $(\mathrm{P}>0.05)$. According to the case of Khuttiyo et al. (2014) study about the effects of alkaloid extracts on growth response and gut histology of nursery pigs. It was found that feed intake and average daily feed intake significantly increased $(\mathrm{P}<0.05)$. Which is in line with the reporting of Wongnen et al. (2019) study was conducted by the effects of tannin sources supplementation on internal nematodes infections in goats. It was found that the supplementation of tannin sources in goats did not affect feed intake, average daily gain, feed conversion ratio and body weight change.

Manila palm (Adonidia merrillii Becc.) supplementation on nutrient digestibility in goat. show in Table 3. The results show that apparent digestibility in terms of dry matter, organic matter, crude protein, neutral detergent fiber and acid detergent fiber were not significant different $(\mathrm{P}>0.05)$. Similarly with Srisaikham (2014) who using neem as goat feed, the results showed that digestibility of dry matter, crude proteins and the ability to digest fibers were no statistical difference $(\mathrm{P}>0.05)$. Neem contains substances that have the same effect on eliminating parasites as manila palm. Moreover, Mulisa et al. (2019) reported that apparent DM digestibility recorded was highest in groups supplemented 300 gm neem leaves $(\mathrm{P}<0.05)$ than other groups.

For the manila palm and ivermectin supplementation on blood urea nitrogen and hematocrit at hour 0 and $4 \mathrm{hr}$ were non significantly different among treatment $(\mathrm{P}>0.05)$. This may be due to the thick feed that goats get, there are not more protein levels than needed. As a result, the amount of $\mathrm{NH}_{3}-\mathrm{N}$ absorbed from the rumen is not available. It does not reflect too much BUN concentration or too low at $10.38-10.93 \mathrm{mg} / \mathrm{dl}$. According to Lloyd (1982) normal levels of BUN in goats range from 11.2-27.7 mg/dl. The concentration of a normal BUN varies depending on several factors such as age, feed, the amount of edible protein, especially $\mathrm{NH}_{3}$ $\mathrm{N}$ levels in the rumen. Therefore, an increase in $\mathrm{NH}_{3}-\mathrm{N}$ levels in the rumen affects an increase in BUN levels in the blood stream. Concentration of BUN it tells the use of nitrogen consumption and the amount of nitrogen edible (Wannapat 1990). Hematocrit (HCT) it is between $26-29 \%$, with normal levels showing that the goat's health is normal, there is no anemia. Jain (1993) found that PCV or hematocrit the normal range is 22-38 percent. It is one of the key indices used to diagnose or assess the integrity of the goat's body and preliminary animal health. Assessment of blood disorders of the animal, if the PCV value is lower than 
usual, indicates signs of anemia. PCV is higher than usual, pets have symptoms of polycythemia. Caused by the formation of abnormally large red blood cells (Jain 1993).

Table 5 shows the effect of manila palm (Veitchia merrillii Becc.) on rumen fermentation and $\mathrm{CH}_{4}$ production in goats. There were no effects of manila palm (Veitchia merrillii Becc.) on ruminal $\mathrm{pH}, \mathrm{NH}_{3}-\mathrm{N}$, temperature, total VFA and butyric acid $(\mathrm{P}>0.05)$. The concentration of acetic acid was decreased by supplementation of manila palm $(\mathrm{P}<0.05)$ whereas propionic acid was increased $(\mathrm{P}<0.05)$ by goat fed manila palm especially manila palm whola extract $5 \mathrm{ml} /$ goat weight $1 \mathrm{~kg}$ when compare with author group. However, $\mathrm{CH}_{4}$ was decreased $(\mathrm{P}<0.05)$ as result of supplementation of manila palm compared to author group. This could be because of manila palm containing condense tannin (CT). These decrease could be related to the fact that CT can reduce protozoal population. This indicated that manila palm can be used as feed supplementation for goat without any negative effect on rumen fermentation.

Calculated methane production by using volatile fatty acid as a variable and was different among treatments. Moreover, Moss et al. (2000) reported that prediction of methane production by using proportion of volatile fatty acid could elucidate the changing of hydrogen itinerary in rumen ecology. Beef cattle fed $\mathrm{CT}$ reduced estimated $\mathrm{CH}_{4}$ production which is in agreement with previous study of Kongmun et al. (2009).

As shown in Table 6, the total direct count of bacterial and fungal zoospores population were not affected in goats fed ivermectin and manila palm $(\mathrm{P}>0.05)$. Whereas, goats fed manila palm whole decreased the protozoal population $(\mathrm{P}<0.05)$. However, Russell and Rychlik (2001) found that when ruminants are fed with different rations the microbial ecology will be altered accordingly. In the previous studies of Poungchompu et al. (2009) who reported that MPP and soapberry fruit remarkably reduced rumen protozoas. Moreover, plants containing tannins could reduce protozoas as reported by Bhatta et al. (2009).

Influence of manila palm (Adonidia merrillii Becc.) supplementation with seeds in manila palm, manila palm peel and manila palm whole extract $5 \mathrm{ml} /$ goat weight $1 \mathrm{~kg}$, on eradication of gastro-intestinal nematodes compared ivermectin 3.03 microgram $/ \mathrm{kg}$ body weight Figure 1. The results showed that before the goat receives the treatment at day 0 fecal egg was not significant different among treatment $(\mathrm{P}>0.05)$. But after the goat receives treatment at 1, 3, 14 days showed a decrease in the goat's fecal egg count was no significant $(\mathrm{P}>0.05)$. After received treatment at 7 and 21 days the goat's fecal egg count were decrease significantly different $(\mathrm{P}<0.05)$. After that at 28 and 35 days the goat's fecal egg count were increase significantly different $(\mathrm{P}<0.05)$. From the $21^{\text {st }}$ day, the performance decreases and 
the number of eggs after day 21 increases, the life cycle of roundworms in goats is approximately 3-4 weeks (Thedford 1986). Which is consistent with Khongsen and Limcharoen (2014) have studied effects of betel palm and neem bark on removal roundworm in the gastrointestinal tract of hybrid meat goats found that the deworming drug vamizole not different from the extracted water group from the betel palm and neem bark extract 35 days after deworming on days 28 and 35, the number of helminth eggs increased significantly different $(\mathrm{P}<0.05)$.

\section{Conclusions}

This study concluded that supplementation of manila palm whole extract $5 \mathrm{ml} /$ goat weight $1 \mathrm{~kg}$ resulted in increased propionic acid and decreased $\mathrm{CH}_{4}$ production, protozoa population and fecal eggs counts. Thus, feeding of manila palm whole extract $5 \mathrm{ml} /$ goat weight $1 \mathrm{~kg}$ is recommended because it has the best level for use as animal feed supplementation.

\section{Conflict of Interest}

We are don't have any conflict of interest

\section{Acknowledgments}

The authors would like to express their most sincere thanks to the Department of Animal Production Technology, Faculty of Agricultural Technology, Kalasin University for experimental animals and laboratory.

\section{Declaration of Funding}

This research did not receive any specific funding.

Animal Welfare Statement: The authors confirm that the ethical policies of the journal, as noted on the journal's author guidelines page, have been adhered to and the appropriate ethical review committee approval has been received. The authors confirm that they have followed EU standards for the protection of animals used for scientific purposes.

\section{Consent to participate}


Not applicable

\section{Consent for publication}

We accept consent for publication.

261

Code availability

267

\section{Availability of data and material}

Not applicable

Not applicable

\section{Authors' contributions}

Not applicable

\section{References}

AOAC. 1990. Official methods of analysis, $15^{\text {th }}$ ed. Assoc. Off. Anal. Chem., Arlington, VA. ARC. 1984. Nutrient requirements of the ruminants livestock. Commonwealth Agricultural Bureaux, Slough, UK (Supplement No. 1).

Bassey, S.A., Essien, E.E. and Enobong, U.D., 2017. Nutritional Composition and Acute Toxicity Potentials of Archontophoenix tukeri and Adonidia merrilli Kernels. Journal of Pharmaceutical and Biosciences, 5(3): 01-08.

Bhatta, R., Uyeno, Y., Tajima, K., Takenaka, A., Yabumoto, Y., Nonaka, I., Enishi, O. and Kurihara, M., 2009. Difference in the nature of tannins on in vitro ruminal methane and volatile fatty acid production and on methanogenic archaea and protozoal populations. Journal of Dairy Science, 92: 5512-5522.

Crocker, C.L., 1967. Rapid determination of urea nitrogen in serum or plasma without deproteinization. American Journal of Medical Technology, 33: 361-365.

Duke, J.A., 1985. Handbook of medicinal herbs. Boca Raton, FL. CRC Press.

Jain, N.C., 1993. Essential of veterinary hematology. Lea \& Febiger. Philadelphia.

Kaneko, J.J., Harvey, J.W. and Bruss, M.L., 1997. Clinical biochemistry of domestic animals, $5^{\text {th }}$ edn. Academic, California.

Kearl, L.C., 1982. Nutrient requirements of ruminants in developing countries. International Feedstuffs Institute, Utah State University, Logan, UT. 
Khuttiyo, J., Attamangkune, S. and Ruangpanit, Y., 2014. Effects of alkaloid extracts on growth response and gut histology of nursery pigs. National Conference, Kasetsart University, Kamphaeng Saen Campus. $11^{\text {th }}, 1642-1648$.

Kaneko, J.J., Harvey, J.W. and Bruss, M.L., 1997. Clinical biochemistry of domestic animal. $5^{\text {th }}$ Edition. Academic Press Inc., New York.

Kongmun, P., Wanapat, M., Nontaso, N., Nishida, T. and Angthong, W., 2009. Effect of phytochemical and coconut oil supplementation on rumen ecology and methane production in ruminants. In: Proceedings of FAO/IAEA International Symposium on Sustainable Improvement of Animal Production and Health, June 8-11, Vienna, Austria pp. 246-247.

Khongsen, M. and Limcharoen, S., 2014. Effects of Areca catechu Linn. and Azadirachta indica on eradication of gastro-intestinal round worm in crossbred meat goat. Princess of Naradhiwas University Journal, 3: 81-87.

Limcharoen, S., Khongsen, M. and Srisawat, S., 2013. Herbs used for eradication of gastrointestinal nematodes in goats. Princess of Naradhiwas University Journal, 164-173.

Lloyd, S., 1982. Blood characteristics and the nutrition of ruminants. British Veterinary Journal, 138: 70-85.

Moss, A.R. and Jouany, J.P., 2000. Newbold, J. methane production by ruminants: its contribution to global warming. Ann. Zootech, 49: 231-253.

Mulisa, F.D., Diribam G.C. and Kushiram,Y.G., 2019. Effect of feeding different proportions of pigeon pea (Cajanus cajan) and neem (Azadirachta indica) leaves on feed intake, digestibility, body weight gain and carcass characteristics of goats. Veterinary and Animal Science, 8: 100079.

Poungchompu, O., Wanapat, M., Wachirapakorn, C., Wanapat, S. and Cherdthong, A., 2009. Manipulation of ruminal fermentation and methane production by dietary saponins from mangosteen peel and soapberry fruit. J. Agricul. Sci, 63: 389-400.

Planning Divission Department of Livestock Development. 2018. Draft Goat Strategy 20172021. (Cited 2021 January 11) available from: http://planning.dld.go.th/th/index.php/th/policy-menu/194-2016-08- 05-07-23.

Robinson, P.H., Givens, D.I. and Getachew, G., 2004. Evaluation of NRC, UC Davis and ADAS approaches to estimate the metabolizable energy values of feeds at maintenance energy intake from equations utilizing chemical assays and in vitro determinations. Animal Feed Science and Technology, 114: 75-90. 
Russell, J.B. and Rychlik, J.L., 2001. Factors that alter rumen microbial ecology. Science, 292(5519):1119-1122. https://doi.org/10.1126/science.1058830

SAS. 1996. SAS/STAT User's Guide: Version 6. 12. 4th Edition. SAS Institute Inc., Cary, NC. Samuel, M., Sagathewan, S., Thomas, J. and Mathen, G., 1997. An HPLC method for estimation of volatile fatty acids of ruminal fluid. The Indian journal of animal sciences, 67: 805-807.

Schneider, B.H. and Flatt, W.P., 1975. The evaluation of feeding through digestibility experiments. p. 169 Univ. Georgia Press, Athens.

Semae, S., 2007. The Success Way of goat raising by muslim way. Journal of Yala Rajabhat University. 2(1): 72-81.

Srisaikham, S., 2014. Effects of neem (Azadirachta indica a. Juss. var. Siamensis valeton) Foliage Utilization in meat goat diets on rumen fermentation and productive performances. A Thesis Submitted in Partial Fulfillment of the Requirements for the Degree of Master of Science in Animal Production Technology Suranaree University of Technology.

Taosaen, M., 2020. Amnat charoen provincial special education center, manila palm. [Cited 2021 January 11]. Available from: http://www.amnatspecial.com/index.php?mod=blog \&path=blog\&id_sub=137.

Thongpea, S., 2015. Effect of tamarind seed supplementation on gastrointestinal nematode and productive performance in growing goats, dissertation. Suranaree University of Technology.

Thedford, T.R., 1986. Goat health handbook: A field guide for procedure with limited veterinary survicus. Winrock International, USA.

Van Soest, P.J., Robertson, J.B. and Lewis, B.A., 1991. Methods for dietary fiber neutral detergent fiber, and nonstarch polysaccharides in relation to animal nutrition. Journal of Dairy Science, 74: 3583-3597.

Panipat, M., 1990. Ruminant Animal Science. Funnie Folding Co, Ltd, Bangkok.

Wongnen, C., Kabploy, K., Summpunn, P., Phetsuwan, W. and Jitpakdee, J., 2019. Effects of tannin sources supplementation on internal nematodes infections in goats. Journal of Khon Kaen Agr. J. 47 (2): 893-898. 
Figures

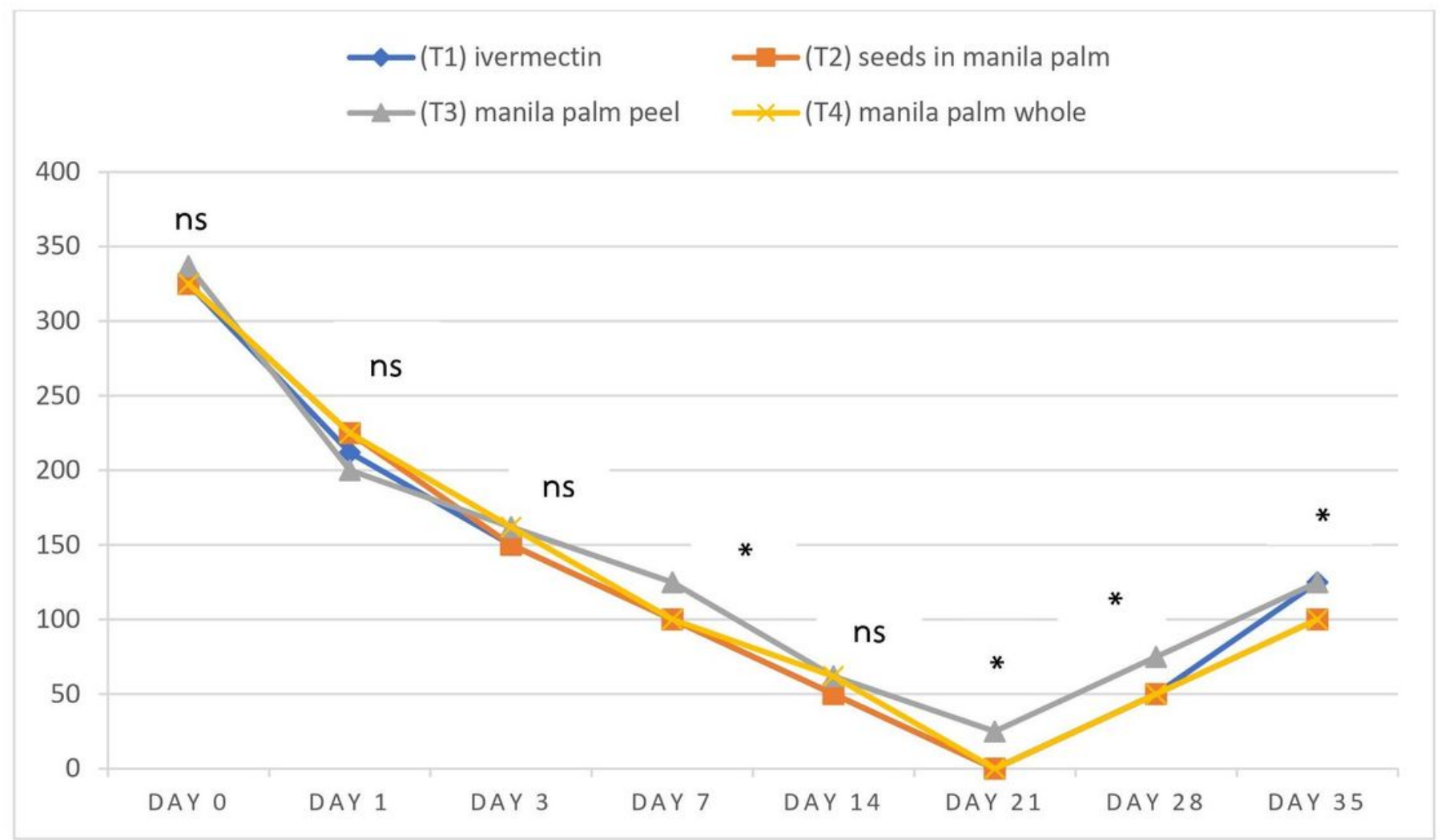

Figure 1 Shown efficiency of manila palm (Adonidia merrillii Becc.) supplementation on roundworm eggs in goat's gastro-intestinal nematodes tract of goat.

Figure 1

Please See image above for figure legend.

\section{Supplementary Files}

This is a list of supplementary files associated with this preprint. Click to download.

- Table.pdf 